\title{
BOSCIA ALBITRUNCA: REVIEW OF ITS BOTANY, MEDICINAL USES, PHYTOCHEMISTRY, AND BIOLOGICAL ACTIVITIES
}

\author{
ALFRED MAROYI* \\ Department of Botany, Medicinal Plants and Economic Development Research Centre, University of Fort Hare, Private Bag X1314, Alice \\ 5700, South Africa. Email: amaroyi@ufh.ac.za
}

Received: 14 August 2019, Revised and Accepted: 02 September 2019

\begin{abstract}
Boscia albitrunca is a medium-sized tree widely used as herbal medicine in Southern Africa. The current study critically reviewed the botany, medicinal uses, phytochemistry, and pharmacological activities of B. albitrunca. Literature on botany, medicinal uses, phytochemical, and biological activities of B. albitrunca was collected from multiple internet sources including Elsevier, Google Scholar, SciFinder, Web of Science, PubMed, BMC, Science Direct, and Scopus. Complementary information was gathered from pre-electronic sources such as books, book chapters, theses, scientific reports, and journal articles obtained from the university library. This study revealed that the species is used as herbal medicine in $75.0 \%$ of the countries in Southern Africa where the species is indigenous. The bark, leaves, and roots of B. albitrunca are mainly used as herbal medicines for constipation, epilepsy, hemorrhoids, headache, human immunodeficiency virus/acquired immune deficiency syndrome, skin diseases, syphilis, and as ethnoveterinary medicine. Ethnopharmacological research identified phenolic compounds, alkaloids, coumarins, flavonoids, saponins, steroids, tannins, and triterpernoids from leaves of B. albitrunca. The crude extracts of the species and the compound martynoside isolated from B. albitrunca exhibited antibacterial and antifungal activities. B. albitrunca should be subjected to detailed phytochemical, pharmacological, and toxicological evaluations aimed at correlating its medicinal uses with its phytochemistry and pharmacological activities.
\end{abstract}

Keywords: Boscia albitrunca, Capparaceae, Herbal medicine, Indigenous knowledge, Southern Africa.

(C) 2019 The Authors. Published by Innovare Academic Sciences Pvt Ltd. This is an open access article under the CC BY license (http://creativecommons. org/licenses/by/4. 0/) DOI: http://dx.doi.org/10.22159/ajpcr.2019.v12i10.35337

\section{INTRODUCTION}

Boscia albitrunca (Burch.) Gilg \& Gilg-Ben. is a medium-sized evergreen tree belonging to the Capparaceae or caper family. B. albitrunca is regarded as a multipurpose tree species in Southern Africa [1-19] used as coffee or tea substitute, source of dye or tannin, fodder, ethnoveterinary medicine, herbal medicine, famine food, food additive, and shade. The leaves of $B$. albitrunca are browsed by livestock and game, especially at the time of flowering and toward the end of the dry season [20-26]. The roots of B. albitrunca are edible and sometimes pounded and cooked into porridge [27-29]. The fruits of B. albitrunca are edible or are used to produce a sweet drink made by mixing the berries with water or milk or used as a flavoring agent [30-33]. The roots, bark, or fruits of B. albitrunca are dried, roasted, and pounded and used as substitute for chicory, coffee, or tea $[2,25,34]$. However, Steyn [34] argued that drinking this tea or coffee prepared from B. albitrunca bark, fruits of leaves causes severe nausea and other gastrointestinal troubles, especially in the novice. In Botswana and Namibia, roots of $B$. albitrunca are used to preserve fermented milk and also serve as a flavoring agent [24,31,32]. In Botswana and Swaziland, bark of B. albitrunca is used as a dye or a tannin [13,17]. $B$. albitrunca is managed in home gardens as herbal medicine in the Limpopo Province in South Africa [35]. Roots of B. albitrunca are sold in informal herbal medicine markets in South Africa [36-38] and Zimbabwe [36] as herbal medicine. B. albitrunca appears to be an important source of herbal medicine within its distributional range in Southern Africa and therefore, there is need for formal documentation and systematic research which is beneficial to indigenous and traditional systems of herbal medicine $[29,39,40]$. It is within this context that this review was undertaken aimed at reviewing the botany, medicinal uses, and biological activities of B. albitrunca so as to provide baseline data required in evaluating the therapeutic potential of the species.

\section{BOTANICAL PROFILE OF B. ALBITRUNCA}

The genus name Boscia Lam. is in honor of a French naturalist, botanist, zoologist, and horticulturist Louis Auguste Guillaume Bosc
(1759-1828) [41]. The species name "albitrunca" is a contraction of two Latin words "albi" which means "white" and "trunca" which means "trunk" in reference to the whitish trunk of the young branches of the species $[42,43]$. B. albitrunca is commonly referred to as "shepherd tree" in English because the evergreen crown of the species cast a small but deep shadow in which for centuries shepherds and their flocks have rested [44]. Synonyms of B. albitrunca include Boscia puberula Pax., Boscia pechuelii Kuntze, Boscia transvaalensis Pestal., Capparis albitrunca Burch., and Capparis punctata Burch. [22,43-54]. B. albitrunca is a stocky, small evergreen tree, growing up to $9 \mathrm{~m}$ in height with a round, much-branched crown, and rigid branchlets $[14,55,56]$. The bark is smooth, gray to whitish-gray in color. The leaves are often clustered on reduced shoots, oblanceolate to elliptic in shape, leathery, and gray-green to green in color above and below. The flowers are small, sweetly scented, and yellowish-green in color, occurring in dense clusters on short lateral shoots. The fruit is a berry, which is spherical in shape, hairless and yellowish in color. This species has been recorded in Angola, Botswana, Namibia, South Africa, Swaziland, Zambia, and Zimbabwe [45-54]. The species has been recorded in dry, open woodland, bushveld, semi-desert areas and often on termitaria in sandy, and loamy and calcrete soils [6] at an altitude ranging from $5 \mathrm{~m}$ to $1850 \mathrm{~m}$ above sea level [48].

\section{MEDICINAL USES OF B. ALBITRUNCA}

Ethnomedicinal information on $B$. albitrunca has been found in Botswana, Namibia, South Africa, Swaziland, and Zambia, representing $75.0 \%$ of the countries where the species is indigenous. The country with the highest ethnomedicinal uses is South Africa with 11 literature records, followed by Namibia with nine literature records, Mozambique with four literature records, Botswana, Swaziland and Zambia with three literature records each (Table 1). The bark, leaves, and roots of $B$. albitrunca are mainly used as herbal medicines for constipation, epilepsy, hemorrhoids, headache, human immunodeficiency virus/acquired immune deficiency syndrome 
Table 1: Medicinal applications of Boscia albitrunca

\begin{tabular}{|c|c|c|c|}
\hline Medicinal use & Parts used & Country & References \\
\hline Constipation & Leaves and roots & Mozambique and Namibia & {$[32,60]$} \\
\hline Diarrhea & Leaves & Mozambique & {$[61]$} \\
\hline Ear problems & Leaves & Namibia & [62] \\
\hline Emetic & Leaves and roots & Swaziland & {$[17,63]$} \\
\hline Epilepsy & Bark, fruits, leaves, and roots & $\begin{array}{l}\text { Namibia, South Africa, and } \\
\text { Swaziland }\end{array}$ & {$[17,24,29,30,63-67]$} \\
\hline Eye problems & Leaves & South Africa & [65] \\
\hline Haemorrhoids & Fruits, leaves and roots & $\begin{array}{l}\text { Botswana, Mozambique, Namibia, } \\
\text { South Africa, and Swaziland }\end{array}$ & {$[17,30,42,52,55,61,63,65]$} \\
\hline Headache & Roots & Namibia and South Africa & {$[32,68,69]$} \\
\hline HIV/AIDS & $\begin{array}{l}\text { Mixed with roots of Elephantorrhiza } \\
\text { elephantina (Burch.) Skeels, Plectranthus } \\
\text { ciliatus E.Mey., and Peltophorum africanum } \\
\text { Sond. }\end{array}$ & South Africa & {$[57-59]$} \\
\hline HIV/AIDS & Roots & South Africa and Zambia & {$[18,35,70,71]$} \\
\hline Magical purposes & Roots & South Africa & [64] \\
\hline Muscular pain & Roots & Mozambique & [60] \\
\hline Respiratory infections & Roots & South Africa & [73] \\
\hline $\begin{array}{l}\text { Skin diseases (chickenpox and } \\
\text { rash) }\end{array}$ & Leaves and roots & Botswana and Namibia & {$[25,74]$} \\
\hline Snakebite & Bark & South Africa & {$[66]$} \\
\hline Syphilis & Leaves, roots, and stems & Namibia and Zambia & {$[71,74-76]$} \\
\hline $\begin{array}{l}\text { Ethnoveterinary medicine (anthrax, } \\
\text { chicken diseases, fertility, retained } \\
\text { placenta, eye, liver, and lung } \\
\text { infections) }\end{array}$ & Bark, leaves, and roots & $\begin{array}{l}\text { Botswana, Namibia, South Africa, } \\
\text { and Zambia }\end{array}$ & {$[42,52,55,77-85]$} \\
\hline
\end{tabular}

HIV/AIDS: Human immunodeficiency virus/acquired immune deficiency syndrome

(HIV/AIDS), skin diseases, syphilis, and as ethnoveterinary medicine (Table 1 and Fig. 1). Other minor medicinal uses recorded in a single country or based on a single literature record include ear problems, emetic, eye problems, galactagogue, hypertension, magical purposes, muscular pain, respiratory infections, and snakebite (Table 1 ). The roots of $B$. albitrunca are mixed with roots of Elephantorrhiza elephantine (Burch.) Skeels, Plectranthus ciliatus E.Mey., and Peltophorum africanum Sond. as herbal medicine for HIV/AIDS [57-59].

\section{PHYTOCHEMICAL AND MINERAL COMPOSITION OF B. ALBITRUNCA}

Table 2 provides values of macro- and micro-elements, rare earth, and trace elements and nutritional composition of leaves, roots, stems, and twigs of B. albitrunca (Table 2). Pendota et al. [65] identified a phenolic compound martynoside (3-hydroxy-4-methoxyphenethyl 3-0- $\alpha$-Lrhamnopyranosyl-4-0-(3-methoxy-4-hydroxy-trans-cinnamoyl)- $\beta$-Dglucopyranoside) from leaves of B. albitrunca. Iikasha [86] and Iikasha et al. [87] isolated alkaloids, coumarins, flavonoids, saponins, steroids, tannins, and triterpernoids from leaves of B. albitrunca. Future research should focus on evaluating the biological activities of the isolated compounds.

\section{BIOLOGICAL ACTIVITIES OF B. ALBITRUNCA}

The following biological activities have been reported from leaf and fruit extracts of $B$. albitrunca and the compound martynoside isolated from the species: Antibacterial $[65,86,87,94,95]$ and antifungal $[65,94]$ activities.

\section{Antibacterial activities}

Pendota et al. [65] evaluated antibacterial activities of crude, dichloromethane, ethyl acetate, and butanol leaf extracts of B. albitrunca and the compound martynoside isolated from the species against Bacillus subtilis, Staphylococcus aureus, Escherichia coli, and Klebsiella pneumoniae using the microdilution technique with neomycin $(0.1 \mathrm{mg} / \mathrm{mL})$ as a positive control. The extracts exhibited

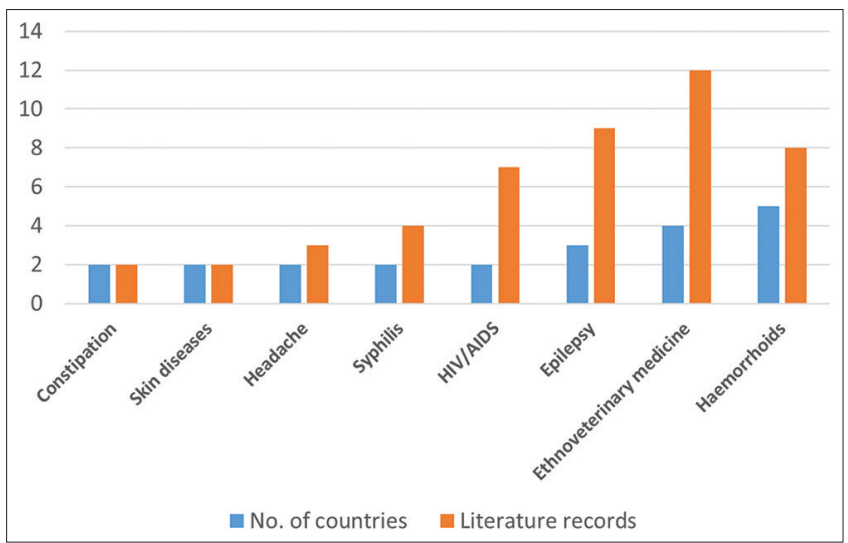

Fig. 1: Medicinal applications of Boscia albitrunca derived from literature records

activities with minimum inhibitory concentration (MIC) values ranging from $390.0 \mu \mathrm{g} / \mathrm{mL}$ to $6250.0 \mu \mathrm{g} / \mathrm{mL}$, while the compound martynoside exhibited MIC values ranging from $7.8 \mu \mathrm{g} / \mathrm{mL}$ to $125.0 \mu \mathrm{g} / \mathrm{mL}$ and the positive control exhibited MIC values ranging from $0.4 \mu \mathrm{g} / \mathrm{mL}$ to $1.6 \mu \mathrm{g} / \mathrm{mL}$ [65]. Pendota et al. [94] evaluated antibacterial activities of $80 \%$ ethanol extracts of $B$. albitrunca seedlings grown under different environmental conditions such as smoke, water, nutrient levels, and nutrient deficiency treatments. The antibacterial activities were evaluated against $B$. subtilis, S. aureus, E. coli, and $K$. pneumoniae using the microdilution assay with neomycin $(0.1 \mathrm{mg} / \mathrm{ml})$ as a positive control. The extracts exhibited activities with MIC values ranging from $0.4 \mathrm{mg} / \mathrm{ml}$ to $6.3 \mathrm{mg} / \mathrm{ml}$, while the control exhibited MIC values ranging from $0.4 \mu \mathrm{g} / \mathrm{ml}$ to $1.6 \mu \mathrm{g} / \mathrm{ml}$ [94]. Iikasha [86] and Iikasha et al. [87] evaluated antibacterial activities of aqueous and organic leaf extracts of B. albitrunca against E. coli, Shigella boydii, S. aureus, Salmonella typhi, and Listeria monocytogenes using the disc and broth dilution methods with vancomycin $(10 \mu \mathrm{g})$, gentamycin $(30 \mu \mathrm{g})$, tetracycline $(35 \mu \mathrm{g})$, 
Table 2: Phytochemical and mineral composition of Boscia albitrunca

\begin{tabular}{|c|c|c|c|}
\hline Phytochemical and mineral composition & Values & Plant parts & References \\
\hline Acid detergent fiber (g/kg of dry matter) & $281.6-292.2$ & Leaves and stems & {$[88,89]$} \\
\hline Acid detergent lignin (g/kg of dry matter) & $128.5-140.0$ & Leaves and stems & {$[88,89]$} \\
\hline Aluminium (ppm) & 3481.9 & Leaves & {$[90]$} \\
\hline Antimony (ppm) & 0.1 & Leaves & [90] \\
\hline Arsenic (ppm) & 1.2 & Leaves & {$[90]$} \\
\hline Ash (g/100 g) & 1.8 & Roots & {$[91,92]$} \\
\hline Barium (ppm) & 357.0 & Leaves & [90] \\
\hline Beryllium (ppm) & 0.1 & Leaves & [90] \\
\hline Bismuth (ppm) & 0.04 & Leaves & [90] \\
\hline Boron (ppm) & 406.0 & Leaves & [90] \\
\hline Caesium (ppm) & 1.9 & Leaves & [90] \\
\hline Calcium (mg/100 g) & 63.6 & Roots & {$[91,92]$} \\
\hline Carbohydrates (g/100 g) & 19.8 & Roots & {$[91,92]$} \\
\hline Cerium (ppm) & 5.7 & Leaves & {$[90]$} \\
\hline Chromium (ppm) & 59.0 & Leaves & [90] \\
\hline Cobalt (ppm) & 2.8 & Leaves & {$[90]$} \\
\hline Copper (mg/100 g) & 0.08 & Roots & {$[91,92]$} \\
\hline Crude fiber $(\mathrm{g} / 100 \mathrm{~g})$ & 3.6 & Roots & {$[91,92]$} \\
\hline Crude protein (g/kg of dry matter) & $195.8-253.3$ & Leaves and stems & {$[88,89]$} \\
\hline Dry matter digestibility (\%) & 68.9 & Leaves and twigs & [93] \\
\hline Dysprosium (ppm) & 0.4 & Leaves & [90] \\
\hline Energy (kj/100 g) & 449.0 & Roots & {$[91,92]$} \\
\hline Erbium (ppm) & 0.2 & Leaves & [90] \\
\hline Europium (ppm) & 0.3 & Leaves & [90] \\
\hline Fat $(\mathrm{g} / 100 \mathrm{~g})$ & 0.2 & Roots & {$[91,92]$} \\
\hline Gadolinium (ppm) & 0.5 & Leaves & [90] \\
\hline Gallium (ppm) & 1.9 & Leaves & [90] \\
\hline Germanium (ppm) & 0.02 & Leaves & [90] \\
\hline Gold (ppb) & 5.4 & Leaves & [90] \\
\hline Hafnium (ppm) & 0.02 & Leaves & [90] \\
\hline Holmium (ppm) & 0.1 & Leaves & [90] \\
\hline Indium $(\mathrm{ppm})$ & 0.1 & Leaves & [90] \\
\hline In vitro dry matter digestibility (g/kg of dry matter) & $558.4 \pm 21.4$ & Leaves and stems & [88] \\
\hline Iron $(\mathrm{mg} / 100 \mathrm{~g})$ & 0.4 & Roots & {$[91,92]$} \\
\hline Lanthanum (ppm) & 4.2 & Leaves & [90] \\
\hline Lead (ppm) & 12.1 & Leaves & [90] \\
\hline Lithium (ppm) & 5.6 & Leaves & [90] \\
\hline Lutetium (ppm) & 0.02 & Leaves & [90] \\
\hline Magnesium (mg/100 g) & 75.8 & Roots & {$[91,92]$} \\
\hline Manganese (ppm) & 879.5 & Leaves & [90] \\
\hline Mercury (ppm) & 1.3 & Leaves & {$[90]$} \\
\hline Moisture (g/100 g) & 68.1 & Roots & {$[91,92]$} \\
\hline Neodymium (ppm) & 2.7 & Leaves & {$[90]$} \\
\hline Neutral detergent fiber (g/kg of dry matter) & $369.2-428.8$ & Leaves and stems & {$[88,89]$} \\
\hline Neutral detergent insoluble ( $\mathrm{g} / \mathrm{kg}$ of dry matter) & $8.3 \pm 1.2$ & Leaves and stems & [88] \\
\hline Nickel (ppm) & 75.7 & Leaves & {$[90]$} \\
\hline Nicotinic acid (mg/100 g) & 0.2 & Roots & {$[91,92]$} \\
\hline Niobium (ppm) & 0.4 & Leaves & [90] \\
\hline Organic matter (g/kg of dry matter) & 924.4 & Leaves & [89] \\
\hline Palladium (ppm) & 0.04 & Leaves & [90] \\
\hline Phosphorus (mg/100 g) & 14.4 & Roots & {$[91,92]$} \\
\hline Potassium (mg/100 g) & 504.0 & Roots & {$[91,92]$} \\
\hline Praseodymium (ppm) & 0.8 & Leaves & {$[90]$} \\
\hline Protein (g/100 g) & 6.5 & Roots & {$[91,92]$} \\
\hline Riboflavin (mg/100 g) & 0.03 & Roots & {$[91,92]$} \\
\hline Rubidium (ppm) & 31.5 & Leaves & [90] \\
\hline Scandium (ppm) & 0.9 & Leaves & [90] \\
\hline Selenium (ppm) & 2.8 & Leaves & [90] \\
\hline Silver (ppm) & 0.2 & Leaves & [90] \\
\hline Sodium (mg/100 g) & 37.2 & Roots & {$[91,92]$} \\
\hline Strontium (ppm) & 627.8 & Leaves & [90] \\
\hline Sulphur (\%) & 1.0 & Leaves & [90] \\
\hline Tannin $(\%)$ & 68.9 & Leaves and twigs & [93] \\
\hline Tantalum (ppm) & 0.003 & Leaves & [90] \\
\hline Tellurium (ppm) & 0.1 & Leaves & [90] \\
\hline Terbium (ppm) & 0.1 & Leaves & [90] \\
\hline Thallium (ppm) & 0.01 & Leaves & [90] \\
\hline Thiamin (mg/100 g) & 0.02 & Roots & {$[91,92]$} \\
\hline Thorium (ppm) & 0.7 & Leaves & [90] \\
\hline Thulium (ppm) & 0.03 & Leaves & [90] \\
\hline Tin (ppm) & 0.3 & Leaves & {$[90]$} \\
\hline
\end{tabular}


Table 2: Phytochemical and mineral composition of Boscia albitrunca(Continued)

\begin{tabular}{|c|c|c|c|}
\hline Phytochemical and mineral composition & Values & Plant parts & References \\
\hline Titanium (ppm) & 144.0 & Leaves & [90] \\
\hline Total phenol (g/kg of dry matter) & 24.7 & Leaves & [89] \\
\hline Total tannin (g/kg of dry matter) & 9.1 & Leaves & [89] \\
\hline Tungsten (ppm) & 0.6 & Leaves & [90] \\
\hline Uranium (ppm) & 0.1 & Leaves & [90] \\
\hline Vanadium (ppm) & 8.2 & Leaves & [90] \\
\hline Vitamin C (mg/100 g) & 6.6 & Roots & {$[91,92]$} \\
\hline Yttrium (ppm) & 2.2 & Leaves & {$[90]$} \\
\hline Zinc (mg/100 g) & 0.8 & Roots & {$[91,92]$} \\
\hline Zirconium (ppm) & 0.6 & Leaves & [90] \\
\hline
\end{tabular}

and ampicillin $(15 \mu \mathrm{g} / \mathrm{ml})$ as positive controls. The extracts exhibited activities with MIC values ranging from $125.0 \mu \mathrm{g} / \mathrm{ml}$ to $>1000.0 \mu \mathrm{g} / \mathrm{ml}$ against the tested pathogens $[86,87]$. Tshikalange et al. [95] evaluated antibacterial activities of crude fruit extracts of $B$. albitrunca against Salmonella typhimurium, Streptococcus pyogenes, Bacillus cereus, K. pneumonia, and Privotella intermedia using microdilution technique. The extract exhibited activities with MIC values ranging from $6.3 \mathrm{mg} / \mathrm{mL}$ to $>25.0 \mathrm{mg} / \mathrm{mL}$ and minimum bactericidal concentration (MBC) values ranging from $12.5 \mathrm{mg} / \mathrm{mL}$ to $>25.0 \mathrm{mg} / \mathrm{mL}$ against the tested pathogens [95].

\section{Antifungal activities}

Pendota et al. [65] evaluated antifungal activities of crude, dichloromethane, ethyl acetate, and butanol leaf extracts of B. albitrunca and the compound martynoside isolated from the species against Candida albicans using the microdilution technique with amphotericin B $(0.1 \mathrm{mg} / \mathrm{ml})$ as a positive control. The extracts exhibited activities with MIC and minimum fungicidal concentration (MFC) values ranging from $390.0 \mu \mathrm{g} / \mathrm{mL}$ to $6250.0 \mu \mathrm{g} / \mathrm{mL}$ and $780.0 \mu \mathrm{g} / \mathrm{mL}$ to $6250.0 \mu \mathrm{g} / \mathrm{mL}$, respectively, while the compound martynoside exhibited MIC and MFC values ranging from $62.5 \mu \mathrm{g} / \mathrm{mL}$ to $250.0 \mu \mathrm{g} / \mathrm{mL}$ and the positive control exhibited MIC and MFC values of $0.2 \mu \mathrm{g} / \mathrm{mL}$ and $9.8 \mu \mathrm{g} / \mathrm{mL}$, respectively [65]. Pendota et al. [94] evaluated antifungal activities of $80 \%$ ethanol extracts of B. albitrunca seedlings grown under different environmental conditions such as smoke, water, nutrient levels, and nutrient deficiency treatments. The antifungal activities were evaluated against $C$. albicans using the microdilution assay with amphotericin B $(0.1 \mathrm{mg} / \mathrm{ml})$ as a positive control. The extracts exhibited activities with MIC values ranging from $0.4 \mathrm{mg} / \mathrm{ml}$ to $6.3 \mathrm{mg} / \mathrm{ml}$, MFC values ranged from $0.4 \mathrm{mg} / \mathrm{ml}$ to $6.3 \mathrm{mg} / \mathrm{ml}$, while the control exhibited MIC and MFC values of $0.2 \mu \mathrm{g} / \mathrm{ml}$ and $9.8 \mu \mathrm{g} / \mathrm{ml}$, respectively [94].

\section{CONCLUSION}

The present review summarizes the ethnomedicinal uses, phytochemistry, and biological activities of the bark, leaves, root bark, and roots extracts of $B$. albitrunca. The historical traditional usage of B. albitrunca as herbal medicine in Southern Africa calls for detailed phytochemical and pharmacological studies aimed at correlating its documented ethnomedicinal uses with the phytochemical and pharmacological properties of the species. There is need for clinical and toxicological evaluations of both crude extracts and phytochemical compounds associated with B. albitrunca.

\section{ACKNOWLEDGMENTS}

The author would like to express his gratitude to Govan Mbeki Research and Development Centre (GMRDC), University of Fort Hare, for financial support to conduct this study.

\section{AUTHOR'S CONTRIBUTIONS}

The author declares that this work was done by the author named in this article.

\section{CONFLICTS OF INTEREST}

The author declares that there are no conflicts of interest regarding the publication of this paper.

\section{REFERENCES}

1. Watt JM, Breyer-Brandwijk MG. Medicinal and Poisonous Plants of Southern and Eastern Africa. London: E and S Livingstone; 1962.

2. Teichler GH. Notes on the Botswana pharmacopoea. Botsw Notes Rec 1971;3:8-11

3. Netshiungani EN. Notes on the uses of indigenous trees in Venda. J Dendrol 1981;1:12-7.

4. Fox FW, Young ME. Food from the Veld: Edible Wild Plants of Southern Africa. Johannesburg: Delta Books; 1982.

5. Peters CR, O’Brien EM, Drummond RB. Edible Wild Plants of Subsaharan Africa. London: Royal Botanic Gardens, Kew; 1992.

6. Venter F, Venter JA. Making the Most of Indigenous Trees. Pretoria: Briza Publications; 1996.

7. Rankoana SA. Aspects of the Ethnobotany of the Dikgale Community in the Northern Province. MSc Dissertation. Sovenga: University of Limpopo; 2000

8. Arnold TH, Prentice CA, Hawkes LC, Snyman EE, Tomalin M, Crouch NR, et al. Medicinal and Magical Plants of Southern Africa: An Annotated Checklist. Pretoria: Strelitzia 13, National Botanical Institute; 2002

9. Moteetee A, Van Wyk BE. Sesotho names for exotic and indigenous edible plants in Southern Africa. Bothalia 2006;36:25-32.

10. Van Wyk B, Van Wyk P, Van Wyk BE. Photo Guide to Trees of Southern Africa. Pretoria: Briza Publications; 2008.

11. Botha J, Weiersbye IM. Ethnobotanic and forage uses of plants on mine properties in the Witwatersrand basin gold fields, South Africa. In: Fourie A, Tibbett M, Wiertz J, editors. Mine Closure. Perth: Australian Centre for Geomechanics; 2010. p. 325-42.

12. Rampedi TI. Indigenous Plants in the Limpopo Province: Potential for their Beverage Production. PhD Thesis. Pretoria: University of South Africa; 2010.

13. Koloka O, Moreki C. Tanning hides and skins using vegetable tanning agents in Hukuntsi sub-district, Botswana. J Agric Technol 2011;7:915-22

14. Van Wyk B, Van Wyk P. Field Guide to Trees of Southern Africa. Cape Town: Penguin Random House; 2013.

15. Tshisikhawe MP, Malunga G. Ethnobotanical profile of indigenous tree species protected within dryland agricultural farming system. Res Rev J Agric Allied Sci 2017;6:15-21.

16. Magwede K, Van Wyk BE, Van Wyk AE. An inventory of Vhavenda useful plants. S Afr J Bot 2019;122:57-89.

17. Masarirambi MT, Zwane PE, Surana N, Kunene EN, Moyo S, Mabuza LL, et al. Indigenous dye plants of the kingdom of Eswatini, traditional uses and new prospects. Adv Med Plant Res 2019;7:8-14

18. Mogale MM, Raimondo DC, Van Wyk BE. The ethnobotany of central Sekhukhuneland, South Africa. S Afr J Bot 2019;122:90-119.

19. Moteetee A, Moffett RO, Seleteng-Kose L. A review of the ethnobotany of the basotho of Lesotho and the free state province of South Africa (South Sotho). S Afr J Bot 2019;122:21-56.

20. Cole MM, Brown RC. The vegetation of the Ghanzi area of Western Botswana. J Biogeogr 1976;3:169-96.

21. Brundin J, Karlsson P. Browse and Browsers in South-western Kalahari: Minor Field Studies. Uppsala: Swedish University of Agricultural Sciences, Report No. 73; 1999. 
22. Schmidt E, Lötter M, McCleland W. Trees and Shrubs of Mpumalanga and Kruger National Park. Johannesburg: Jacana Media; 2002.

23. Alias D, Milton S, Herrmann E, Seymour C. A Collation and Overview of Research Information on Boscia albitrunca (Shepherd's Tree) and Identification of Relevant Research Gaps to Inform Protection of the Species. Pretoria: Department of Water Affairs and Forestry; 2003.

24. Msangi JP. Food Security among Small-scale Agricultural Producers in Southern Africa. New York: Springer; 2014.

25. Neelo J, Kashe K, Teketay D, Masamba W. Ethnobotanical survey of woody plants in Shorobe and Xobe villages, Northwest region of Botswana. Ethnobot Res Appl 2015;14:367-79.

26. Mudzengi CP, Murwira A, Zengeya FM, Murungweni C. Screening key browse species in a semi-arid rangeland. Cogent Food Agric 2017;3:1285854.

27. Bothma J, du P. There's no end to the shepherd's tree. Custos $1982 ; 11: 17-21$

28. Mabogo DEN. The Ethnobotany of the Vha Venda. MSc Dissertation. Pretoria: University of Pretoria; 1990.

29. Van Wyk BE, Gericke N. People's Plants: A Guide to Useful Plants of South Africa. Pretoria: Briza Publications; 2007.

30. Van Damme P, Van Den Eynden V, Vernemmen P. Plant uses by the Topnaar of the Kuiseb valley Namib desert. Afr Focus 1992;8:223-52.

31. Motlhanka DM, Motlhanka P, Selebatso T. Edible indigenous wild fruit plants of Eastern Botswana. Int J Poult Sci 2008;7:457-60.

32. Cheikhyoussef A, Embashu W. Ethnobotanical knowledge on indigenous fruits in Ohangwena and Oshikoto regions in Northern Namibia. J Ethnobiol Ethnomed 2013;9:34

33. Ketlhoilwe MJ, Jeremiah K. The role of traditional ecological knowledge in natural resources management: A case study of village communities in Eastern part of Botswana. Eur J Educ Stud 2016;2:29-43.

34. Steyn DG. The drinking of coffee and tea: Its effects on the human and animal system. S Afr J Chem 1973;26:3-11

35. Semenya SS, Potgieter MJ. Medicinal plants cultivated in bapedi traditional healers homegardens, Limpopo province, South Africa. Afr J Tradit Complement Altern Med 2014;11:126-32.

36. Cunningham AB. African Medicinal Plants: Setting Priorities at the Interface between Conservation and Primary Health Care. Paris: People and Plants Working Paper 1, UNESCO; 1993.

37. Williams VL, Balkwill K, Witkowski ET. A lexicon of plants traded in the Witwatersrand umuthi shops, South Africa. Bothalia 2001;31:71-98.

38. Moeng TE. An Investigation into the Trade of Medicinal Plants by Muthishops and Street Vendors in the Limpopo Province, South Africa. MSc Dissertation. Sovenga: University of Limpopo; 2010.

39. Maity D, Sandur VR. An updated review on herbal drugs: Nootropic activity and possible mechanisms. Asian J Pharm Clin Res 2019;12:19-26.

40. Apoorva HA, Mehdi S, Krishna KL, Nabeel K. Medicinal herbs and phytochemicals used in the treatment of depression: A review. Asian J Pharm Clin Res 2019;12:8-14.

41. Quattrocchi U. CRC World Dictionary of Medicinal and Poisonous Plants: Common Names, Scientific Names, Eponyms, Synonyms, and Etymology. Boca Raton: Taylor and Francis Group; 2012.

42. Govender M. Boscia albitrunca (Burch.) Gilg and Gilg-Ben; 2005. Available from: http:/www.pza.sanbi.org/boscia-albitrunca. [Last accessed on 2019 Jul 11].

43. Hyde MA, Wursten BT, Ballings P, Palgrave CM. Boscia albitrunca (Burch.) Gilg and Gilg-Ben: Flora of Zimbabwe; 2019. Available from: https://www.zimbabweflora.co.zw/speciesdata/species.php?species id=124480. [Last accessed on 2019 Jul 15].

44. Palmer E, Pitman P. Trees of Southern Africa Covering all known Indigenous Species in the Republic of South Africa, South West Africa, Botswana, Lesotho and Swaziland. Cape Town: AA Balkema; 1972.

45. Wild H. Capparidaceae. In: Exell AW, Wild H, editors. Flora Zambesiaca. Vol. 1. London: Flora Zambesiaca Managing Committee; 1960. p. 194-245.

46. Drummond RB. A list of trees, shrubs and woody climbers indigenous or naturalised in Rhodesia. Kirkia 1975;10:229-85.

47. Roodt V. Trees and Shrubs of the Okavango Delta Shell Field Guide Series. Gaborone: Shell Oil Botswana; 1998.

48. Germishuizen G, Meyer NL. Plants of Southern Africa: An Annotated Checklist. Pretoria: Strelitzia 14, National Botanical Institute; 2003.

49. Mapaura A, Timberlake J. A Checklist of Zimbabwean Vascular Plants. Pretoria: Southern African Botanical Diversity Network Report No. 33; 2004.

50. Setshogo MP. Preliminary Checklist of the Plants of Botswana. Pretoria: Southern African Botanical Diversity Network Report No. 37; 2005

51. Figueiredo E, Smith GF. Plants of Angola. Pretoria: Strelitzia 22,
National Botanical Institute; 2008.

52. Heath A, Heath R. Field Guide to the Plants of Northern Botswana Including the Okavango Delta. London: Kew Publishing, Kew; 2009.

53. Mannheimer CA, Curtis BA. Le Roux and Müller's Field Guide to the Trees and Shrubs of Namibia. Windhoek: Macmillan Education Namibia; 2009.

54. Burrows JE, Burrows SM, Lötter MC, Schmidt E. Trees and Shrubs of Mozambique. Cape Town: Publishing Print Matters (Pty); 2018.

55. Palgrave MC. Keith Coates Palgrave Trees of Southern Africa. Cape Town: Struik Publishers; 2002.

56. Snijman DA. The extra Cape flora. In: Plants of the Greater Cape Floristic Region. Vol. 2. Pretoria: Strelitzia 30, South African National Biodiversity Institute; 2013.

57. Semenya SS, Potgieter MJ, Erasmus LJ. Ethnobotanical survey of medicinal plants used by Bapedi traditional healers to manage HIV/ AIDS in the Limpopo province, South Africa. J Med Plants Res 2013;7:434-41.

58. Semenya SS, Potgieter MJ, Erasmus LJ. Bapedi phytomedicine and their use in the treatment of sexually transmitted infections in Limpopo province, South Africa. Afr J Pharm Pharmacol 2013;7:250-62.

59. Maroyi A. Elephantorrhiza elephantina: Traditional uses, phytochemistry and pharmacology of an important medicinal plant species in Southern Africa. Evid Based Complement Alternat Med 2017;2017:1-18

60. Bruschi P, Morganti M, Mancini M, Signorini MA. Traditional healers and laypeople: A qualitative and quantitative approach to local knowledge on medicinal plants in muda (Mozambique). J Ethnopharmacol 2011;138:543-63.

61. Ribeiro A, Romeiras MM, Tavares J, Faria MT. Ethnobotanical survey in Canhane village, district of Massingir, Mozambique: Medicinal plants and traditional knowledge. J Ethnobiol Ethnomed 2010;6:33.

62. Van den Eynden V, Van Dammen P. Medicinal and aromatic plants used by the Topnaar: Namibia. Acta Hortic 1993;330:75-84.

63. Long C. Swaziland's Flora: Siswati Names and Uses. Mbambane, Swaziland: Swaziland National Trust Commission; 2005. Available from: http://www.sntc.org.sz/index.asp. [Last accessed on 2019 Jun 14].

64. Sobiecki JF. A review of plants used in divination in Southern Africa and their psychoactive effects. South Afr Hum 2008;20:1-19.

65. Pendota SC, Aderogba MA, Van Staden J. In vitro antimicrobial activity of extracts and an isolated compound from Boscia albitrunca leaves. S Afr J Bot 2015;96:91-3.

66. Maema LP, Mahlo SM, Potgieter MJ. Ethnomedicinal uses of indigenous plant species in Mogalakwena municipality of Waterberg district, Limpopo province South Africa. Int J Tradit Complement Med 2016;1:28-44.

67. Masondo NA, Stafford GI, Aremu AO, Makunga NP. Acetylcholinesterase inhibitors from Southern African plants: An overview of ethnobotanical, pharmacological potential and phytochemical research including and beyond Alzheimer's disease treatment. S Afr J Bot 2019;120:39-64

68. Semenya SS, Maroyi A. Ethnobotanical survey of plants used by Bapedi traditional healers to treat tuberculosis and its opportunistic infections in the Limpopo province, South Africa. S Afr J Bot 2019;122:401-21.

69. Semenya SS, Maroyi A. Source, harvesting, conservation status, threats and management of indigenous plant used for respiratory infections and related symptoms in the Limpopo province, South Africa. Biodiversitas 2019;20:790-811.

70. Semenya SS, Potgieter MJ, Erasmus LJ. Indigenous plant species used by Bapedi healers to treat sexually transmitted infections: Their distribution, harvesting, conservation and threats. S Afr J Bot 2013;87:66-75.

71. Chinsembu KC. Ethnobotanical study of medicinal flora utilised by traditional healers in the management of sexually transmitted infections in Sesheke district, Western Province, Zambia. Rev Brasil Farmacogn 2016;26:268-74.

72. Semenya SS, Wadesango N. Ethnobotanical survey of plants used by bapedi traditional healers to treat hypertension in the Polokwane munucipality, Limpopo province, South Africa. Indilinga Afr J Indig Knowl Syst 2018;17:109-29.

73. Semenya SS, Maroyi A. Source of plants, used by Bapedi traditional healers for respiratory infections and related symptoms in the Limpopo province, South Africa. J Biol Sci 2019;19:101-21.

74. Cheikhyoussef A, Shapi M, Matengu K, Ashekele HM. Ethnobotanical study of indigenous knowledge on medicinal plant use by traditional healers in Oshikoto region, Namibia. J Ethnobiol Ethnomed 2011;7:10.

75. Hedimbi M, Chinsembu KC. Ethnomedicinal study of plants used to manage HIV/AIDS-related disease conditions in the Ohangwena 
region, Namibia. Int J Med Plants Res 2012;1:4-11.

76. Chinsembu KC, Hijarunguru A, Mbangu A. Ethnomedicinal plants used by traditional healers in the management of HIV/AIDS opportunistic diseases in Rundu, Kavango East region, Namibia. S Afr J Bot 2015;100:33-42

77. Gabanakgosi K, Moreki JC, Nsoso SJ, Tsopito C. Ethnoveterinary medicine usage in family chickens in the selected four villages of Botswana. J Vet Adv 2012;2:586-94.

78. Gabalebatse M, Ngwenya BN, Teketay D, Kolawole OD. Ethnoveterinary practices amongst livestock farmers in Ngamiland district, Botswana. Afr J Tradit Complement Altern Med 2013;10:490-502.

79. Moreki JC, Tshireletso K, Okoli IC. Potential use of ethnoveterinary medicine for retained placenta in cattle in Mogonono, Botswana. J Anim Prod Adv 2012;2:303-9.

80. Moreki JC. Documentation of ethnoveterinary practices used in family poultry in Botswana. Vet World 2013;6:18-21.

81. Setlalekgomo MR, Setlalekgomo T. The use of ethnoveterinary medicine in goats in Lentsweletau village in Kweneng district of Botswana. J Vet Adv 2013;3:197-202.

82. Chinsembu KC, Negumbo J, Likando M, Mbangu A. An ethnobotanical study of medicinal plants used to treat livestock diseases in Onayena and Katima Mulilo, Namibia. S Afr J Bot 2014;94:101-7.

83. Chinsembu KC. Indigenous knowledge and antimicrobial properties of plants used in ethnoveterinary medicine. In: Chinsembu KC, Cheikhyoussef A, Mumbengegwi D, Kandawa-Schulz M, Kasanda CD, Kazembe L, editors. Indigenous Knowledge of Namibia. Windhoek: University of Namibia; 2015. p. 115-34.

84. Nyako U, Bala A, Ardo LM. Management and practices of ethnoveterinary health amongst livestock producers in Africa. Afr J Dairy Farming Milk Prod 2016;3:116-9.

85. Marius LN, Osafo EL, Mpofu ID, Van Der Merwe P, Boys J, AttohKotoku V. Indigenous knowledge and identification of local woody plant species as potential feeds for goats in the communal farming areas of Namibia. Livest Res Rural Dev 2017;29:1

86. Iikasha AM. Phytochemical Screening and Antibacterial Testing of Selected Namibian Medicinal Plants against Laboratory and Clinical Bacteria that Cause Diarrhoea. MSc Dissertation. Windhoek: University of Namibia; 2016

87. Iikasha AM, Bock R, Mumbengegwi DR. Phytochemical screening and antibacterial activity of selected medicinal plants against laboratory diarrheal bacteria strains. J Pharmacogn Phytochem 2017;6:2337-42.

88. Madibela OR, Letso M, Makoba B, Seitshiro O. Do indigenous browse trees influence chemical composition and in vitro dry matter digestibility of parasitic plants? Anim Feed Sci Technol 2004;115:357-69.

89. Theart JJ, Hassen A, Van Niekerk WA, Gemeda BS. In-vitro screening of Kalahari browse species for rumen methane mitigation. Sci Agric 2015;72:478-83.

90. Mshumi U. Can Acacia karroo and Boscia albitrunca spp. be used in the Biogeochemical Prospecting for Gold: A Case Study at the Blue Dot Mine, Amalia, Northwest Province, South Africa. MSc Dissertation. Cape Town: University of the Western Cape; 2006.

91. Arnold TH, Wells MJ, Wehmeyer AS. Khoisan food plants: Taxa with potential for future economic exploitation. In: Wickens GE, Goodin JR, Field DV, editors. Plants for Arid Lands. London: Royal Botanic Gardens, Kew; 1985. p. 67-86.

92. Wehmeyer AS. Edible Wild Plants of Southern Africa: Data on the Nutrient Contents of Over 300 Species. Pretoria: CSIR; 1986.

93. Aganga AA, Adogla-Bessa T. Dry matter degradation, tannin and crude protein contents of some indigenous browse plants of Botswana. Arch Zootec 1999;48:79-83

94. Pendota SC, Kulkarni MG, Van Staden J. Germination, seedling growth requirements and antimicrobial properties of Boscia albitrunca: A keystone species in arid Southern Africa. S Afr J Bot 2016;104:105-11.

95. Tshikalange TE, Modishane DC, Tabit FT. Antimicrobial, antioxidant, and cytotoxicity properties of selected wild edible fruits of traditional medicinal plants. J Herbs Spices Med Plants 2017;23:68-76. 